\title{
INTEGRATION OF THE BASIC AND VOCATIONAL TRAINING OF FUTURE JUNIOR MEDICAL SPECIALISTS IN THE PROCESS OF STUDYING NATURAL SCIENCES
}

\section{Yakovyshena Liudmyla ${ }^{1}$}

DOI: https://doi.org/10.30525/978-9934-571-89-3_38

Today, under the new socio-economic conditions, the reform of healthcare in Ukraine, the role of a medical worker is increasing. New tasks of medical education are the preparation of an initiative person who strives for self-development and selfeducation, capable of creative and personal development. The solution to such tasks requires higher education institutions (HEI) to provide graduates of medical establishments with a high level of knowledge in the professional sector. In medical colleges, the main fundamental disciplines in the vocational training of the future medical specialist are physics, chemistry, mathematics, and astronomy. It is known that the high quality of knowledge can be provided only if they are fundamental [1]. Therefore, the process of studying in medical HEI, in particular in colleges, should be built as a holistic and unified system, which originates from disciplines of natural sciences and is the theoretical basis for the training of future junior medical specialists. The idea is interesting that the study of fundamental disciplines forms the capacity of medical students for analysis, reflection, logical thinking, and the sequence of binding various facts [2]. Therefore, we believe that the professional orientation of the study of fundamental disciplines, in particular, natural sciences, is an important part of the process of forming the professional competencies of future medical workers.

The purpose of the article is to substantiate the role and place of natural sciences' disciplines in the educational process of a medical college.

Let us conduct an analysis of the concepts of "professional orientation" and "interdisciplinary integration", the content of which reveals the fundamental importance of natural sciences in the process of preparing a future junior medical

\footnotetext{
${ }^{1}$ Vinnytsia State Pedagogical University named after Mykhailo Kotsiubynskyi, Ukraine 
specialist. The analysis of psychological and pedagogical sources indicates that a large number of scientific works is devoted to the issues of the professional orientation of education, the scientists point out that the professional orientation is: a system of motives which prompts the professional to perform professional tasks and tasks of professional development [3]; - interest in the profession and the tendency to engage in it [4]; - one of the structural characteristics of the individual means a sufficiently conscious and emotionally expressed orientation to a certain kind and type of professional activity [5]; - a kind of fixation on pedagogical activity and psychological readiness for it [6].

In the study, the professional orientation will be interpreted as an integral characteristic of motivation (interests, needs, purposeful efforts, aspirations, etc.) to the professional activity affecting the choice of future specialty. Under the professional orientation of students studying natural sciences, in particular physics and biophysics of medical institutions of higher education, we understand the organization of their training, in which students purposefully and effectively acquire theoretical knowledge in these disciplines, professional skills to apply this knowledge in practice to solve professional problems, which contributes to the development of professional thinking.

"Integration (from Lat. integer - complete, integral) - is the creation of a new whole based on the identification of same-type elements and parts of several previously disassembled units (educational subjects, types of activities, etc.)" [2].

One of the ways used to achieve integration in the content and forms of education is interdisciplinary relationships that contribute to the formation of holistic knowledge of students. According to M. Fitsula, interdisciplinary relationships are also intended to show such an aspect, when the possibilities of one subject contribute to solving the tasks of another one [6, p. 106]. Polish scholars E. Goźlińska and F. Szlosek believe that the association of knowledge acquired by students in the process of studying various disciplines takes place through the integration of this knowledge in various subjects [9].

Given the above, in the process of studying natural sciences in the medical college, it is necessary to focus on the principle of integration of education, fundamentality, and professional orientation. The very interconnection between the fundamental and professionally oriented (vocational) knowledge during the teaching of general scientific disciplines, and especially physics, should facilitate the unification of these disciplines with professional disciplines.

In medical HEI, the discipline "Physics and Astronomy" is integrated into the discipline "Biological Physics and Medical Equipment". The disadvantage of the content of working programs is non-envisaging of professionally oriented exercises in the process of performing practical works. In our study, we consider it expedient to introduce subject tasks, including exercises of medical content, in the study of this discipline.

Under professionally oriented exercises (qualitative, graphics, computational) we will understand tasks, quantitative characteristics, studying and solving which are useful and necessary for the future professional activity of a medical specialist. We 
propose a classification of professionally oriented exercises in the discipline "Biological Physics and Medical Equipment" which includes exercises devoted to:the specifics of physical phenomena and processes in medical practice; - use of physical phenomena, processes, devices in medicine (application in diagnostics for research, application in medical practice); - a description of the principle of the operation of medical devices, which are inherently physical devices.

Here is an example of a professionally oriented exercise that is proposed to be studied by medical students within the "Mechanics" section of the discipline "Physics and Astronomy".

Exercise. Determine the average linear velocity of blood flow in the vessel with a radius of $15 \mathrm{~mm}$, if during the systole $55 \mathrm{ml}$ of blood pass through it. Suppose the duration of systole is $0,2 \mathrm{~s}$.

$R=0,015 \mathrm{~m}$, The volume of blood flowing through the vessel at time $t$ is determined $V=55 \cdot 10^{-6} \mathrm{~m}^{3}$, by the ratio: $V=S \cdot v \cdot t$, where $S=\pi R^{2}-$ cross-sectional area of the $t=0,2 \mathrm{~s}$ vessel. It follows that: $V=\pi R^{2} \cdot v \cdot t$.

$v-$ ? Let's express the velocity $v=\frac{V}{\pi R^{2} t}$.

Let's substitute numerical values: $v=\frac{55 \cdot 10^{-6}}{3,14 \cdot(0,015)^{2} \cdot 0,2}=\frac{55 \cdot 10^{-6}}{141,3 \cdot 10^{-6}}=0,39 \mathrm{~m} / \mathrm{s}$.

Answer: the blood flow rate is $0,39 \mathrm{~m} / \mathrm{s}$.

Professionally oriented tasks in physics can be used during the training sessions in studying the new material, re-teaching, consolidating and generalizing the learned material, during the organization of in-class and out-of-class individual work of students. Application of such exercises in physics classes in the training of future junior medical specialists increases interest in studying this discipline, promotes the development of students' thinking and understanding of those biological processes occurring in living organisms, as well as deepening understanding of physical methods and actions of technical devices for the diagnosis and research of biosystems, and forms a positive attitude to the chosen profession.

Therefore, integration of natural sciences and medical knowledge, students' skills contributes to the formation of a number of components of productive thinking, is aimed at ensuring the integrity of education. Such integration in the professional training of future medical workers is expedient to be carried out based on natural sciences, which are fundamental at the level of content of cycles of disciplines.

\section{References:}

1. Kuzmyna N. V. Professyonalyzm lychnosty prepodavatelia y mastera proyzvodstvennoho obuchenyia / N. V. Kuzmyna - M. : Vyssh. shk.,1990. - 119 s.

2. Professionalnaya pedagogika: uchebnik dlya studentov, obuchayuschihsya po pedagogicheskim spetsialnostyam i napravleniyam. - 2-e izd., pererab. i dop. - M.: Assotsiatsiya "Professionalnoe obrazovanie", 1999. - 904 s.

3. Slastenin V.A. Professionalnaya gotovnost uchitelya k vospitatelnoy rabote: soderzhanie, struktura, funktsionirovanie // Professionalnaya podgotovka uchitelya v sisteme vyisshego pedagogicheskogo obrazovaniya. - M.: Prosveschenie. - S. 14-28. 4. Stuchynska N.V. Intehratsiia 
fundamentalnoi ta fakhovoi pidhotovky maibutnikh likariv pry vyvchenni fizyko-matematychnykh dystsyplin / N.V. Stuchynska. - K: Knyha-plius, 2008. - 409 s.

5. Smirnova O.V. Rol fundamentalnykh nauk u pidhotovtsi likariv // Tezy dopovidei navch.-metod. konferentsii "Problemy ta perspektyvy vyshchoi medychnoi shkoly u rozrobtsi ta realizatsii natsionalnoi stratehii pobudovy novoi systemy okhorony zdorovia v Ukraini na period 2015-2025 r.r.", Vinnytsia. -2015. $-196 \mathrm{~s}$.

6. Fitsula M.M. Vstup do pedahohichnoi profesii: Navchalnyi posibnyk dlia studentiv vyshchykh pedahohichnykh zakladiv osvity. - 2-he vyd. - Ternopil, 2003. - $136 \mathrm{~s}$.

7. Shadrykov V. D. Diialnist i zdibnosti. - M. : Lohos, 1994. - 315 s.

8. Goźlińska E., Szlosek F. Podnjczny slownik nauczyciela ksztalcenia zawodowego. Radon, 1997. $157 \mathrm{~s}$. 